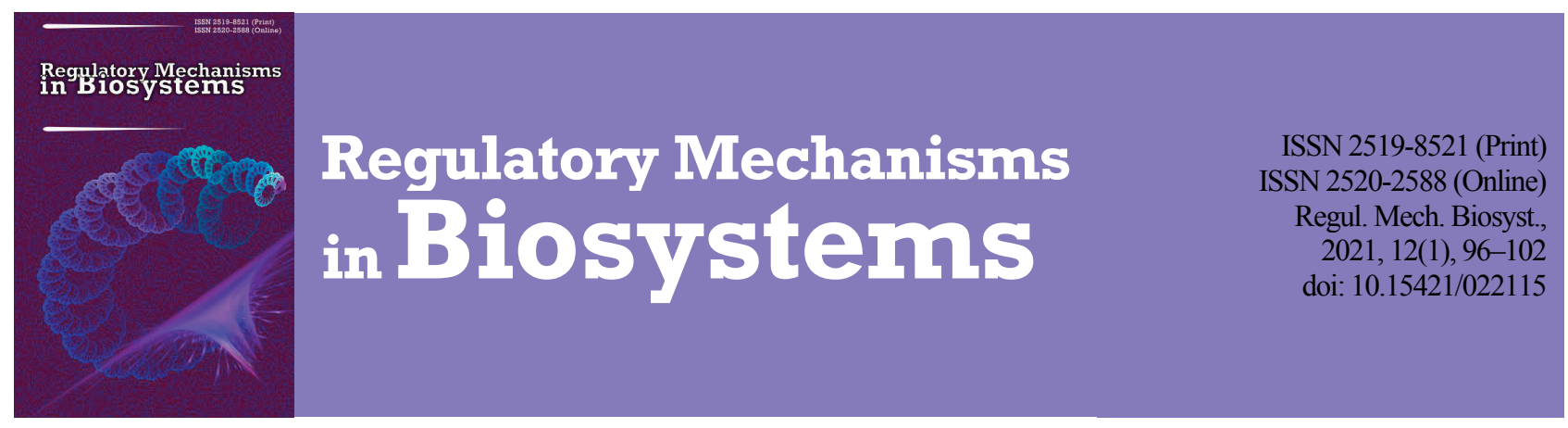

\title{
Structural features of the mesonephros of semianadromous fish on the example of the European smelt (Osmerus eperlanus)
}

\author{
E. A. Flerova \\ P. G. Demidov Yaroslavl State University, Yaroslavl, Russia
}

Article info

Received 08.02.2021

Received in revised form 02.03 .2021

Accepted 03.03.2021

P.G. Demidov Yaroslavl State University,

Sovetskaya st., 14 ,

Yaroslavl, 150003

Russia.

Tel.: +7-485-279-77-02.

E-mail: katari-

num@mail.ru

\begin{abstract}
Flerova, E. A. (2021). Structural features of the mesonephros of semianadromous fish on the example of the European smelt (Osmerus eperlanus). Regulatory Mechanisms in Biosystems, 12(1), 96-102. doi:10.15421/022115
\end{abstract}

At present, special attention is drawn to the study of the adaptation of aquatic organisms to a complex of environmental factors precisely at the cellular level. It is very important to study the structural and functional features of the kidney, which not only plays a key role in osmoregulation, but also makes a significant contribution to maintaining homeostasis at the level of functioning of a single nonspecific defense system of the body. In this aspect, the study of species belonging to a unique ancient group, united in the order salmoniformes, is highly relevant. Using the methods of light and electron microscopy, we investigated the morphology and ultrastructure of the mesonephros of the population of the semianadromous ecological form European smelt Osmerus eperlanus inhabiting the Gulf of Finland of the Baltic Sea and performing spawning migrations in the Luga River of the Leningrad Region. The general scheme of the trunk kidney organization is given, the structural features and the ratio of leukocytes and structures of the smelt nephron are revealed. It is shown that the development of hematopoietic tissue in the mesonephros, the number of mature forms of granulocytes are systematic signs which do not depend on the ecology of the species. The ratio of leukocytes, the width of the cisterns of the rough endoplasmic reticulum of plasma cells, the structure and number of granules in granulocytes are associated with the peculiarities of the functioning of the cellular link of the immune system under certain conditions of the species habitat. The ultrafine structure of the ion-transporting interstitial cells, as well as the ultrastructural features found in the smelt nephron, can be considered cytological markers of smelt adaptation to a semianadromous lifestyle.

Keywords: kidney; leukocytes; nephron; structure.

\section{Introduction}

Currently, special attention is drawn to the study of adaptive features of hydrobionts to the complex of environmental factors specifically at the cellular level, for the evolution of fishes is inextricably related to the high extent of specialization and adaptive plasticity of this level of organization of living matter. In comparative-evolutional aspect, it is quite important to study the structural-functional peculiarities of the kidney, which not only plays a key role in osmoregulation, but significantly contributes to the support of homeostasis at the level of functioning of the integral non-specific protection of the system of the organism. Furthermore, the kidney is a unique organ of hematopoiesis, where the cells of all lines undergo proliferation and maturation, and completion of all the stages of the immune response regardless of other lymphoid organs are possible (Becker et al., 2001; Resende et al., 2010; Lapirova et al., 2019). Morphology of the kidney of fish has been studied since the 1960s, but for most species of fish there is no information, and an even smaller number of studies are devoted to the ultrastructural studies of the organ. Functional-morphological diversity and specialization of fish related to adaptations to the environment make this a vast sphere of research, which is poorly studied (Resende et al., 2012).

In this aspect, the study of species that belong to a unique ancient group, united in one order of Salmoniformes is highly relevant. This is a group of anadromous, semi-anadromous and freshwater fishes of the Northern Hemisphere that has a number of primitive features in their structure. It has to be noted that in most studies on Salmoniformes undergoing anadromous mutations, the central aspect of studying the mesonephros is solving questions related to the process of smoltification of anadromous Salmoniformes (Mizuno et al., 2001; Björnsson \& Bradley, 2007; Flerova et al., 2020). There are fragmentary surveys related to adaptive changes in the tubules of the nephron occurring in juvenile fish of the Pacific Ocean during migration to the sea, and also of Salmonidae egg producers during spawning migrations (Maksimovich et al., 2000; Maksimovich, 2008). At light-microscopic level, using stereological methods, the characteristic of the essential kidney excretory components of adult individuals of Salmo trutta f. fario depending on sex and season was revealled (Resende et al., 2010). There are surveys of the ultrastructures of the nephrons of mature individuals of four species of freshwater trout (Anderson \& Loewen, 1975). There are no complex studies focusing on peculiarities of the structure of the tissues and ultrastructure of cells of hematopoietic tissues and nephrons of the kidneys of the egg producers of semi-anadromous Salmoniformes in the period of migration.

The Smelt of the Gulf of Finland of the Baltic Sea is a semianadromous fish, one of the most important industrial fish, and an object of sport fishing. Citizens of Saint Petersburg consider smelt the historical symbol of the city. Despite the fact that it is the second most abundant fish (after Atlantic herring) in the ichthyocoenosis of the eastern part of the Gulf of Finland, due to the changes in the ecological situation in the Neva Bay, the populations of this species have sharply decreased over the last decades (Sendek \& Bogdanov, 2019). In the Gulf of Finland, it is represented by two groups: the "Neva" smelt, more abundant, spawning in the Neva, the Neva Bay and neighboring areas; and "Finnish" smelt which spawns in freshwater areas of the mouths of the rivers inflowing to the Gulf. It approaches the shores in spring beginning from late April and starts to spawn in early May. Young fish comprise the main river food base of Salmonidae (Sendek \& Bogdanov, 2019).

The objective of this study was complex research of structural organization of the mesonephros of egg producing smelt (Osmerus eperlanus Linnaeus, 1758). Achieving this goal is significant both theoretically and practically. In theoretical aspect, the data we obtained are an important 
component of comparative-evolutional knowledge about the structure of the kidneys of lower vertebrates. In practical aspect, the results may be used for monitoring aquatic objects.

\section{Materials and Methods}

The smelt were caught in May 2018 in the Luga River, Leningrad Oblast. The Luga River is one of the spawning locations for the wild population of smelt in the basin of the Baltic Sea. In the study, we used 6 specimens of smelt egg producers. The fish were mechanically immobilized, and their body length and weight were then measured. The mesonephroi were extracted, fixated and then studied according to the standard methods of light and electron microscopy.

Table 1

Length, weight, sex and maturity stage of smelt

\begin{tabular}{ccccc}
\hline $\begin{array}{c}\text { Length to the end } \\
\text { of the longest tail fin, } \mathrm{cm}\end{array}$ & $\begin{array}{c}\text { Total } \\
\text { weight, } \mathrm{g}\end{array}$ & $\begin{array}{c}\text { Gutted body } \\
\text { weight, } \mathrm{g}\end{array}$ & Sex & $\begin{array}{c}\text { Stage of maturity } \\
\text { of gonads }\end{array}$ \\
\hline 13.6 & 200 & 180 & 0 & 3 \\
12.8 & 174 & 154 & 0 & 2 \\
13.9 & 126 & 106 & 0 & 2 \\
17.0 & 171 & 134 & ○े & 3 \\
15.9 & 230 & 117 & + & 3 \\
16.2 & 239 & 118 & + & 3 \\
\hline
\end{tabular}

Content and proportion of leukocytes were analyzed using the method of light microscopy on impression smears stained according to Romanovsky-Giemsa. To calculate the leukocytic formula, on the impression smear, using Mikomed-6 microscope, we counted no less than 200 cells. Semi-thin sections of $2-3 \mu \mathrm{m}$ thickness were prepared on a Leica EM UC7 microtome (Leica, Germany, 2007). The dried sections were stained with methylene blue. On a light microtome Mikomed-6 (LOMO-Microsystems, Russia, 2017), from the preparations, we obtained digital photos that were further processed in Image Tool 3.0 software (Vladislav Galyanin, license FreeWare, 2011). We measured the outer diameter (d) of the vessels, the renal corpuscles and the tubules. We calculated the area (S) of the interstitial tissue as the difference between the general area of the section and overall area of the renal corpuscles, tubules and vessels. The ultrathin sections were prepared on the Leica EM UC7 microtome (Leica, Germany, 2007), contrasted using uranyl acetate and lead citrate, and then analyzed under a JEM 1011 electronic microscope (JEOL, Japan, 2007). The measurements were made using digital photos.

Statistical processing was used to calculate mean values and standard errors $(\mathrm{x} \pm \mathrm{SE})$. Correspondence to the normal distribution was evaluated using the Shapiro-Wilk test (W). To examine the differences, we used the Mann-Whitney U-test. As critical level of significance, we took $\mathrm{P}<0.05$. Statistical analysis was performed in Statistica 10 software (StatSoft Inc.).

\section{Results}

At light-microscopic level, the share of the renal interstitium equaled $48.63 \pm 0.98 \%$ of the total area of the section. This tissue surrounds the nephrons and the vessels, the average diameter of the latter equaling $38.23 \pm 2.71 \mu \mathrm{m}$. On the impression smears of the mesonephros interstitium, leukocytes were seen. The most numerous group among the mature leukocytes were lymphocytes, the share of which accounted for $70.45 \pm$ $2.85 \%$. The second most abundant group was represented by early predecessors of leukocytes - haemocytoblasts $(10.00 \pm 1.25 \%)$. Immature forms of granulocytes varied 3-5\% (promyelocytes $-4.95 \pm 0.51 \%$, myelocytes $-3.00 \pm 0.90 \%$, metamyelocytes $-2.80 \pm 0.65 \%$ ). The share of mature forms of cells decreases in the row of stab neutrophils $-3.05 \pm$ $0.40 \%$, plasmatic cells $-2.50 \pm 0.10 \%$, microxyphil neutrophils $-2.00 \pm$ $0.50 \%$, macrophages $-1.50 \pm 0.10 \%$.

Average diameter of the renal corpuscle that forms the beginning of the nephron was $84.51 \pm 6.57 \mu \mathrm{m}$. The renal corpuscle is followed by a tortuous tubule divided into proximal and distal sections. The average diameter of the renal sections of the proximal tubules was $58.94 \pm 1.45 \mu \mathrm{m}$. The average diameter of the renal sections of the distal tubules equaled $71.80 \pm 4.02 \mu \mathrm{m}$. In the renal interstitium, other than leukocytes at different stages of maturity, we found cells with radially positioned vesicles and ion-transporting cells.

The results of the study revealed that a distinctive trait of lymphocytes of smelt is large size, up to $6 \mu \mathrm{m}$, and large round nucleus that almost comprises the entire volume of the cell. Heterochromatin blocks are located both along the nuclear membrane and diffusively distributed almost throughout the area of the nucleus. The cytoplasm contains 3-4 mitochondria and large amount of free ribosomes (Table 2, Fig. 1a).

Plasmatic cells: large, $10-12 \mu \mathrm{m}$ in length, usually oval, with eccentrically located rounded nucleus. Heterochromatin is condensed along the nuclear membrane, and also evenly distributed in the form of infrequent "piles" on the section of the nucleus. The cytoplasm contains cisterns of well developed scabrous endoplasmatic reticulum of average width ranging $0.18 \pm 0.02 \mu \mathrm{m}$, with 3-7 electron-dense lysosomes, and 3-4 mitochondria (Table 2, Fig. 1b).

Macrophages: the largest cells among leukocytes are filled with phagosomes. Many macrophages form melano-macrophage centers (Table 2, Fig. 1c, d).

Table 2

Morphometric parameters of cells of interstitium of mesonephron $(x \pm S E)$

\begin{tabular}{|c|c|c|c|c|c|c|c|}
\hline Parameter & Lymphocyte & Plasmatic cell & Macrophage & Neutrophil & Eosinophil & $\begin{array}{l}\text { Cells with radially } \\
\text { located vesicles }\end{array}$ & $\begin{array}{l}\text { Ion-transporting } \\
\text { cells }\end{array}$ \\
\hline Size of cell, & $5.94 \pm 0.05$ & $10.4 \pm 0.57$ & $13.6 \pm 1.09$ & $10.8 \pm 0.67$ & $12.5 \pm 0.84$ & $6.35 \pm 0.24$ & $21.6 \pm 2.37$ \\
\hline$\mu \mathrm{m}(\mathrm{n}=10)$ & $\times 5.25 \pm 0.33$ & $\times 8.82 \pm 0.52$ & $\times 10.4 \pm 0.81$ & $\times 8.80 \pm 0.60$ & $\times 7.54 \pm 1.34$ & $\times 5.43 \pm 0.35$ & $\times 4.84 \pm 0.29$ \\
\hline Size of nucleus, & $4.68 \pm 0.07$ & $5.15 \pm 0.37$ & $5.98 \pm 0.82$ & $6.02 \pm 0.40$ & $5.36 \pm 0.32$ & $4.67 \pm 0.30$ & $5.64 \pm 0.69$ \\
\hline$\mu \mathrm{m}(\mathrm{n}=10)$ & $\times 3.91 \pm 0.07$ & $\times 4.49 \pm 0.35$ & $\times 4.68 \pm 1.02$ & $\times 3.73 \pm 0.41$ & $\times 3.84 \pm 0.41$ & $\times 3.62 \pm 0.19$ & $\times 3.89 \pm 0.38$ \\
\hline Size of mitochondria, & $0.84 \pm 0.10$ & $1.39 \pm 0.15$ & $0.72 \pm 0.08$ & $0.79 \pm 0.10$ & $1.14 \pm 0.26$ & $0.96 \pm 0.16$ & $0.78 \pm 0.10$ \\
\hline$\mu \mathrm{m}(\mathrm{n}=20)$ & $\times 0.58 \pm 0.05$ & $\times 0.93 \pm 0.04$ & $\times 0.45 \pm 0.03$ & $\times 0.54 \pm 0.09$ & $\times 0.97 \pm 0.35$ & $\times 0.66 \pm 0.06$ & $\times 0.50 \pm 0.11$ \\
\hline $\begin{array}{l}\text { Number of mitochondria } \\
\text { on the cell section }(n=20)\end{array}$ & $3.33 \pm 0.41$ & $3.75 \times 0.29$ & $4.33 \pm 0.24$ & $3.17 \pm 0.74$ & $4.00 \pm 0.58$ & $0.96 \pm 0.16$ & $21.7 \pm 2.86$ \\
\hline $\begin{array}{l}\text { Size of phagosomes / vesicles, } \\
\mu \mathrm{m}(\mathrm{n}=30)\end{array}$ & - & - & $\begin{array}{l}2.86 \pm 0.55 \\
\times 2.26 \pm 0.47\end{array}$ & - & - & $\begin{array}{c}0.62 \pm 0.06 \\
\times 0.39 \pm 0.02\end{array}$ & - \\
\hline $\begin{array}{l}\text { Number of phagosomes / vesicles } \\
\text { on the cell section }(n=30)\end{array}$ & - & - & $12.7 \pm 1.12$ & - & - & $21.0 \pm 1.87$ & - \\
\hline $\begin{array}{l}\text { Size of type I } \\
\text { granules, } \mu \mathrm{m}(\mathrm{n}=30)\end{array}$ & - & - & - & $\begin{array}{c}0.26 \pm 0.01 \\
\times 0.21 \pm 0.01 *\end{array}$ & $\begin{array}{l}0.71 \pm 0.05 \\
\times 0.54 \pm 0.04\end{array}$ & - & - \\
\hline $\begin{array}{l}\text { Size of type II } \\
\text { granules, } \mu \mathrm{m}(\mathrm{n}=30)\end{array}$ & - & - & - & $\begin{array}{c}0.39 \pm 0.02 \\
\times 0.29 \pm 0.01^{* *}\end{array}$ & - & - & - \\
\hline $\begin{array}{l}\text { Size of type III granules, } \\
\mu \mathrm{m}(\mathrm{n}=30)\end{array}$ & - & - & - & $\begin{array}{c}0.60 \pm 0.03 \\
\times 0.42 \pm 0.01 * * *\end{array}$ & - & - & - \\
\hline Number of granules on cell section $(n=30)$ & - & - & - & $16.6 \pm 1.72$ & $103 \pm 12.7$ & - & - \\
\hline
\end{tabular}

Note: "-“" means absence of organelle in this type of cell; * - statistically significant differences between sizes of types I and II granules; ** - statistically significant differences between sizes of types II and III granules; *** - statistically significant differences between sizes of types I and III granules; n-number of altered structures of each group of fish (Mann-Whitney U-test, $\mathrm{P}<0.05$ ). 


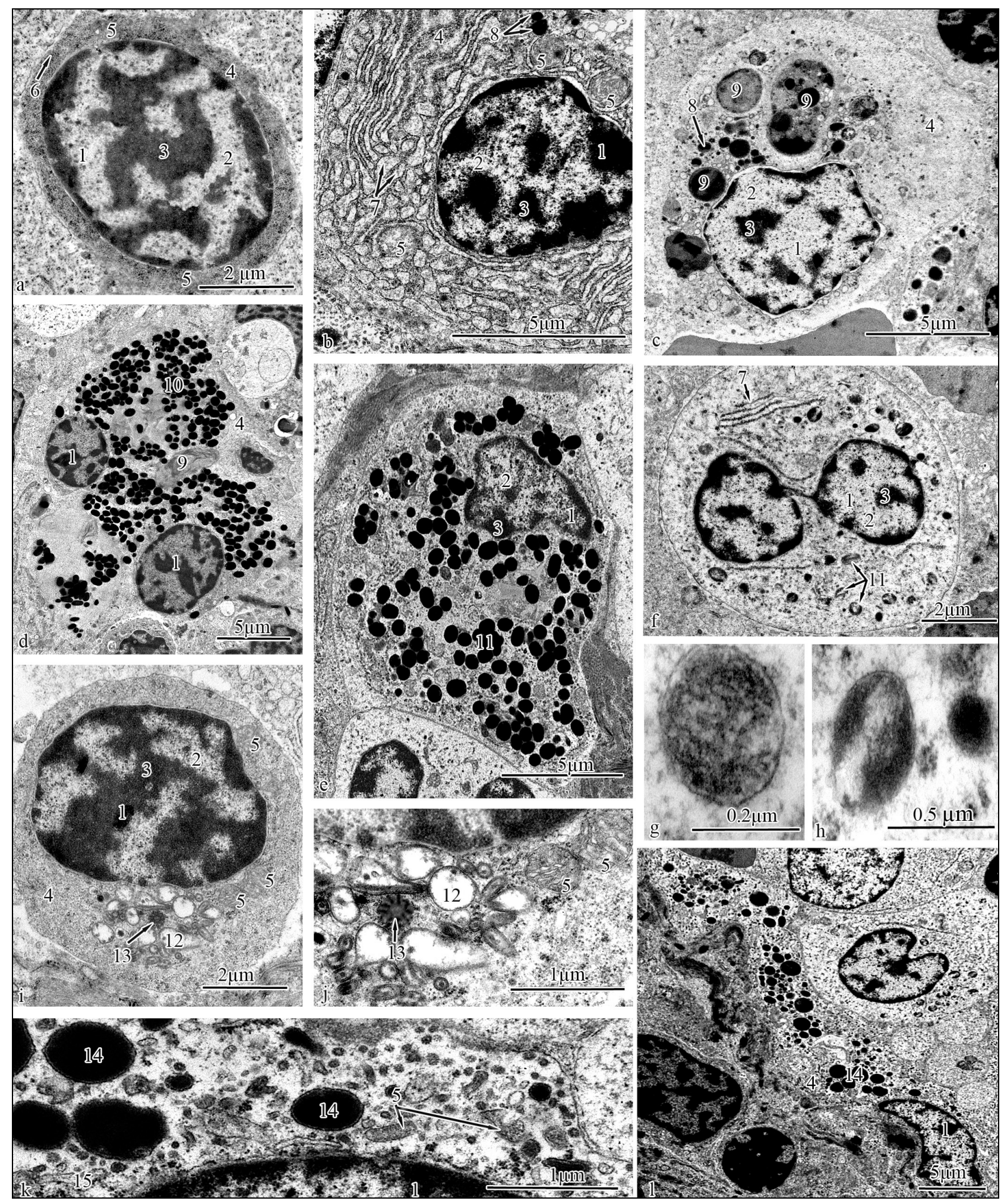

Fig. 1. Ultrastructure of the cells of mesonephros interstitium of smelt: $a$-lymphocyte, $b$-plasmatic cell, $c$-macrophage, $d$-macrophage center,

$e$-eosinophil, $f$-neutrophil, $g$ - specific granules of type II neutrophil, $h$-specific granules of types I and III neutrophil, $i$ - cell with radially arranged

vesicles, $j$-cytoplasm of the cell with radially positioned vesicles, $k$-cytoplasm of ion-transporting cell, $l$-ion-transporting cell; 1 -nucleus;

2 - euchromatin; 3 -heterochromatin; 4 - cytoplasm; 5 -mitochondria; 6 -accumulation of ribosomes; 7 -rough endoplasmic reticulum; 8-lysosomes;

9-phagosomes; 10 - melanin granules; 11 - specific granules; 12 -radial vesicle array; 13 - cintrioli; 14 - granules; 15 -tubular reticulum

Neutrophils: the length ranges 9-14 $\mu \mathrm{m}$, round in shape. The nucleus of young neutrophils is located in the central part of the cell and has rounded or bean-like shape. The shape of the acentric nucleus of mature neutrophils varies from stab to microxyphil. There is little heterochromatin, it is mainly located along the nuclear membrane, and concentrated in the center of the nucleus as several small-sized piles. The cytoplasm contains 2-6 mitochondria, on the sections of some cells we found separate tubules of scabrous endoplasmatic reticulum. A distinctive feature of neutrophils was specific granules that fill the cytoplasm (Table 2, Fig. 1f).

On the sections of neutrophils of the smelts, we found three types of granules. The first type of granules comprised the most homogenous, electron-dense, largest in size, rounded granules, the form factor of which equaled 0.8 (Table 2, Fig. 1h). Type II granules were reliably large, though as compared with the type I granules, oval-shaped (form factor 0.7 ) orga- 
nelles. Along the section of granules, evenly distributed electron-dense fibrils are stretched (Table 2, Fig. 1g). Type III granules were the largest, oval-shaped (form-factor 0.7 ) organelles. The peculiarity of type III granules was presence of electron-transparent center formed as a result of shift of electron-dense fibrils to the periphery of the granule's section (Table 2, Fig. 1h).

Ion-transporting cells: long and narrow cells (Table 2, Fig 11) localize diffusively in the parenchyma of the organ, and also surround the vessels and the tubules of the mesonephros. The round nucleus is positioned closer to the periphery of the cell. There is little heterochromatin, located mostly along the nuclear membrane, and concentrating in the center of nucleus as several small "piles". Cytoplasm is light, contains 28 to
36 elongated mitochondria. On the sections of the cells, there are large electron-dense granules and tubules of endoplasmatic reticulum that are evenly distributed across the entire cell (Table 2, Fig. 1k).

Cells with radially arranged vesicles of 6-7 $\mu \mathrm{m}$ length are rounded in shape. The nucleus is located eccentrically, with bean-like shape, contains a large amount of heterochromatin blocks that comprise the entire section of the nucleus. The cytoplasm is grainy, but less dense compared with lymphocytes, contains short cisterns of smooth endoplasmic reticulum (Table 2, Fig. 1i). In the apical part of the sections of cells, we found a cellular center sending out radially oriented electron-transparent vesicles, and near them, we observed 3-5 large oval mitochondria (Table 2, Fig. 1j).

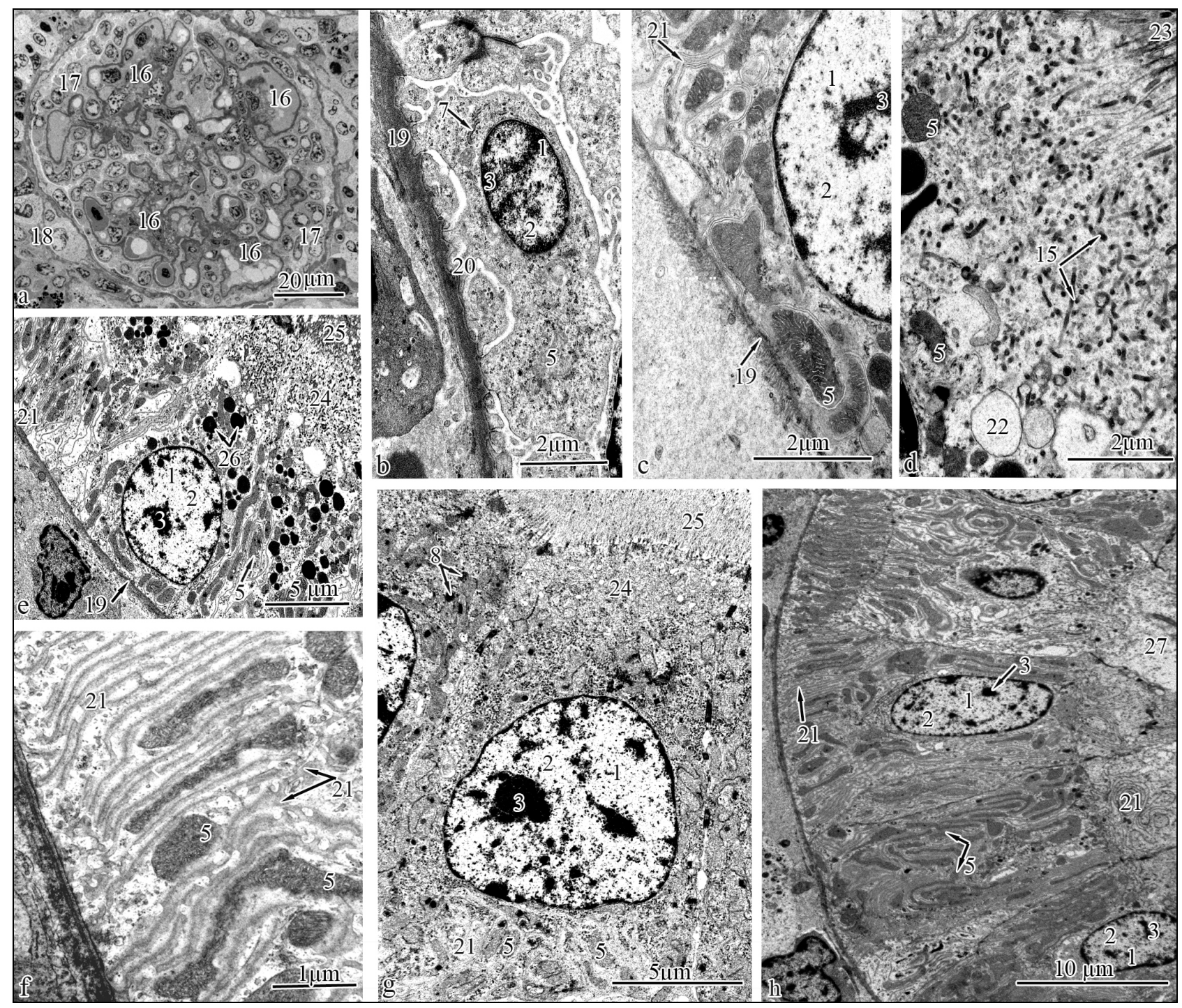

Fig. 2. Ultrastructure of the nephron of smelt: $a$-renal corpuscle, $b$-podocyte, $c$-basal part of type I epitheliocyte of the proximal tubule, $d$-zone of endocytosis of type I epitheliocyte of the proximal tubule, $e$ - type I epitheliocyte of the proximal tubule, $f$-basal part of epitheliocyte of the distal tubule, $g$-type II epitheliocytes of the proximal tubule, $h$-epitheliocytes of the distal tubule; 1 -nucleus; 2 - euchromatin; 3 -heterochromatin;

5 -mitochondria; 7 -rough endoplasmic reticulum; 8-lysosomes; 15 -tubular reticulum, 16 -blood vessel; 17 -podocytes; 18 -interstitial tissue; 19-basement membrane; 20 - podocyte legs; 21 - smooth endoplasmic reticulum; 22 - vesicle; 23 - microvilli, 24 - endocytosis zone, 25 - brush border, 26 - secretory granules, 27 - blade-shaped cytoplasmic processes

Eosinophils: the length varies $12-14 \mu \mathrm{m}$, rounded in shape. The nucleus is rounded, located in the central part in young eosinophils, and shifted toward the periphery in mature cells. Heterochromatin is present in small amount, located chiefly along the nuclear membrane, and concentrated as small piles in the center of the nucleus. A distinctive feature of eosinophils is presence of rounded (form-factor 0.76) electron-dense granules of homogenous structure in the cytoplasm. It has to be noted that average amount of granules on the sections of eosinophils was 6 times the amount of granules on sections of neutrophils. Granules of eosinophils were larger than granules of neutrophils (Table 2, Fig. 1c). The renal corpuscle forms the first section of the nephron. It comprises the Bowman's capsule and a glomerulus of capillaries. The Bowman's capsule is composed of two layers: external and internal. Between the layers, there is $1.46 \pm 0.54 \mu \mathrm{m}$ cavity, to which the glomerular filtrate is being introduced from the lumen of the capillaries. Diameter of the vessels varied 20 $47 \mu \mathrm{m}$, (average diameter $32.98 \pm 5.62$ ). The external layer of the capsule is composed of a one-layer flat epithelium on the basal membrane (Fig. 2a). The internal layer is made of podocytes, located on the external 
surface of the capillary glomerulus. The podocytes are elongated cells, the apical part of which develops the spicules of the podocyte, adjacent to the membrane. Between the spicules and the membrane, there is a filtration fissure. The nuclei of podocytes are round in shape; heterochromatin is distributed evenly on all the section of nucleus. In the cytoplasm, we detected 2-3 mitochondria, separate cisterns of scabrous endoplasmatic reticulum, free ribosomes (Table. 3, Fig. 2b). Thickness of the basal membrane of the internal layer of the capsule equaled $0.64 \pm 0.08 \mu \mathrm{m}$.

Type I epitheliocytes of the proximal tubule develop its beginning. These cells are the highest among other types of cells of the proximal tubule (Table 3). They are elongated cells, pyramidal in shape, located densely close one to another. The nuclei are rounded, located in the basal part of the cells. On the sections of nuclei, the main area is occupied by euchromatin, while heterochromatin is to a higher extent located as a narrow contour along the nucleus and several piles that are evenly distributed on its area. Grainy cytoplasm contains 50-58 mitochondria (Table 3). From the basal part, along the cells, there run numerous cords of plasmatic membrane that further transform into the system of tubules of the smooth endoplasmic reticulum. Such folds are distinctive for all the types of epitheliocytes of all the sections of the tubule (Fig. 2c, e). In the basal part of type I epitheliocytes, the membrane surrounds the mitochondria that are oriented perpendicular in relation to the length of the cell, thus causing folds (Table 3, Fig. 2c). There are lysosomes and large electrondense secretory granules characteristic of this region of the nephron (Ta- ble 3, Fig 2e). The number of secretory granules varied 8-14. In the apical part of cells, at the border with the brush border, there is a well developed zone of endocytosis (Table 3, Fig. 2d). This zone is characterized by presence of a tubular-vesicular system. Endoplasmic reticulum is presented by separate tubules that do not develop the ramified system of tubules (Fig. 2d). The brush border is the highest for this type of epitheliocyte. It comprises a large amount of microvilli oriented toward the tubule lumen. Moreover, there occurred singular cells,the brush border of which was composed of villi. The villi cells on the sections of the tubules were rarely seen (Table 3 ).

Type II epitheliocytes of the proximal tubule are cells that, according to the scheme of structure, are similar to the cells of I type, but reliably lower in height (Table 3). Type II nuclei, as in type I cells, are round, located in the basal part of the cells. There is little heterochromatin, most part of which is located along the nuclear membrane, between the nuclear pores. Cytoplasm is less grainy, contains fewer mytochondria, which in the basal part of the cell are arranged along the length-wise axis of the cells. Mytochondria of type II epitheliocytes are longer compared with type I epitheliocytes (Table 3, Fig. 2g). A distinctive trait of type II epitheliocytes is the absence of secretory granules in the cytoplasm. The zone of endocytosis is more poorly developed compared with type I cells, though the presence of the tubular-vesicular system is clearly noticeable (Table 3 , Fig. 2g). The brush border is lower than in type I cells. Villi cells on the sections of the tubules occurred rarely (Table 3 ).

Table 3

Morphometric parameters of the structures of nephron $(x \pm S E)$

\begin{tabular}{|c|c|c|c|c|}
\hline Parameter & $\begin{array}{l}\text { Podocyte of the } \\
\text { renal corpuscle }\end{array}$ & $\begin{array}{l}\text { Type I epitheliocytes } \\
\text { of the proximal tubule }\end{array}$ & $\begin{array}{l}\text { Type II epitheliocytes } \\
\text { of the proximal tubule }\end{array}$ & $\begin{array}{c}\text { Epitheliocytes } \\
\text { of the distal tubule }\end{array}$ \\
\hline Size of cell, $\mu \mathrm{m}$ & $9.14 \pm 0.71 \times 5.38 \pm 1.59$ & $18.8 \pm 0.25 \times 13.4 \pm 0.39$ & $16.8 \pm 1.70^{*} \times 12.3 \pm 1.04$ & $22.1 \pm 0.63 \times 16.7 \pm 1.70$ \\
\hline Size of nucleus, $\mu \mathrm{m}$ & $4.74 \pm 1.26 \times 3.31 \pm 0.98$ & $8.08 \pm 0.56 \times 7.15 \pm 0.40$ & $6.25 \pm 0.75 \times 5.13 \pm 0.97$ & $9.03 \pm 0.16 \times 5.76 \pm 0.66$ \\
\hline Size of mitochondria, $\mu \mathrm{m}$ & $0.88 \pm 0.03 \times 0.52 \pm 0.10$ & $1.56 \pm 0.19 \times 0.76 \pm 0.08$ & $1.78 \pm 0.19 * \times 0.72 \pm 0.11$ & $\begin{array}{c}1.13 \pm 0.26 \times 0.62 \pm 0.08^{1} \\
2.98 \pm 0.16^{*} \times 0.54 \pm 0.06^{2}\end{array}$ \\
\hline Number of mitochondria on cell section & $2.50 \pm 0.39$ & $34.0 \pm 2.83$ & $48.5 \pm 4.96$ & $49.0 \pm 5.04$ \\
\hline Size of secretory granules, $\mu \mathrm{m}$ & - & $1.23 \pm 0.12 \times 1.07 \pm 0.08$ & - & - \\
\hline Number of secretory granules on cell section & - & $11.67 \pm 2.27$ & - & - \\
\hline Size of endocytosis zone & - & $4.67 \pm 0.24$ & $3.88 \pm 0.53$ & - \\
\hline Size of brush border & - & $3.29 \pm 0.22$ & $3.06 \pm 0.23$ & - \\
\hline Size of villi & - & $0.24 \pm 0.00$ & $0.24 \pm 0.01$ & - \\
\hline Size of microvilli & - & $0.11 \pm 0.01$ & $0.16 \pm 0.01$ & - \\
\hline
\end{tabular}

Note: "- "means absence of organelle in this type of cells; ${ }^{1}$ - basal part of cell, ${ }^{2}$ - apical part of cell; * - statistically significant differences between the height of epitheliocytes, length of mitochondria of types I and II epitheliocytes of the proximal tubule, length of mitochondria of the basal and apical parts of epitheliocytes of the distal tubule (MannWhitney U-test, $\mathrm{P}<0.05)$.

Epitheliocytes of the distal tubule develop high and very wide-at-thebase cells (Table 3). Nuclei of most cells were concentrated in the central position, sometimes shifted toward the basal part. Distribution of heterochromatin is similar to that in nuclei of epitheliocytes of the proximal tubules (Fig. 2h). The cytoplasm of the basal part of epitheliocytes of the distal tubules is characterized by large elongated mytochondria and tubules of smooth endoplasmic reticulum, oriented toward the longitudinal axis of the cell. Approaching the nucleus, the reticulum develops a ramified system of tubules (Table 3, Fig, 2f). There is no zone of endocytosis. The apical part of the cells forms the lobe-like cytoplasmic projections oriented towards the lumen of the tubule. On the lobe-like projections, we found spreading of cytoplasmic membrane (Fig. 2h).

\section{Discussion}

The research has provided the data on the structural organization of the mesonephros of Osmerus eperlanus. Histological analysis revealed that the body kidney of smelt has the same type of structure as that of Salmoniformes that live in freshwater bodies, as well as those that make anadromous migrations. The mesonephros of smelt, similarly to other Salmoniformes, contains the following necessary components: hematopoietic tissue that develops the renal interstitium, nephrons and vessels. In the mesonephros interstitium, we identified erythrocytes, lymphocytes, plasmatic cells, singular macrophages and macrophagous centers, neutrophils and eosinophils at different stages of maturity. We found cells with radially positioned vesicles and ion-transporting cells (Balabanova, 2006; Katoh, 2008; Flerova \& Balabanova, 2013; Flerova et al., 2020). At the same time, analysis of the results revealed the peculiarities of the structural organization of mesonephros of smelt compared with freshwater Salmoniformes (Artamonova et al., 2017). Diameter of the renal corpuscle, proximal and distal tubules of the nephron were found to be greater in semianadromous smelt captured during spawning migration than in freshwater Esox lucius L., 1758 (Lapirova et al., 2017). The degree of the development of the hematopoietic tissue of smelt was much lower compared with this tissue in the mesonephros of E. lucius, which is the basal phylogenetic branch in relation to Salmoninae, Thymallinae and Coregoninae (Yasuike et al., 2010; Artamonova et al., 2017; Lapirova et al., 2017). The peculiarities of the development of hematopoietic tissue in the studied organ are likely related to the processes of development of blood cells in the renalspleen type of hematopoiesis, which manifest already at the level of different systematic groups and do not depend on species ecology.

Analysis of content and proportion of leukocytes exhibited two types of granulocytes in the hematopoietic tissue - neutrophils and eosinophils. Earlier, it was shown that in the hematopoietic tissue of the representatives of Salmo gaidneri Richardson, 1836, only one type of granulocytes occurs - neutrophils (Kocabatmaz \& Ekingen, 1987). Two types of granulocytes were also observed in the mesonephros of Esox lucius, Salmo salar L., 1758, S. trutta L., 1758 (Flerova, 2017; Lapirova et al., 2017). The number of mature forms of granulocytes may be identified to systematic traits of the species.

Values of the shares of particular type of leukocytes varied within a narrow range. The highest inter-species variability was seen for lymphocytes. Interestingly, the ratio of leukocytes had a broad norm of reaction, quickly reacting to changes in the environment. An earlier, study revealled 
that the share of neutrophils of Coregonus albula L, 1758 in various regions of the Beloye Ozero ranged $41-88 \%$, equaling on average $74 \%$ (Keyster, 2009). The ratio of lymphocytes of the mesonephros of smelt corresponded to this parameter in the mesonephros of Coregonus albula (Keyster, 2009). Relative total amount of mature cells and macrophages of smelt was twice as high as that of Esox lucius. Relative amount of mature granulocytes in the kidney of Osmerus eperlanus was somewhat higher compared with Esox lucius (Lapirova et al., 2017). The great difference in the share of granulocytes between freshwater species in the fattening period and smelt which migrate is most likely related to the peculiarities of functioning of phagocytes and antibody-forming cells in the conditions of spawning migrations. Similar changes in the leukocytic formula were observed in Silurus granis L., 1758 that had suffered ichthyophthiriasis (Mikryakov et al., 2019). Moreover, this presumption is coherent with the data on the ultrastructure of the plasmatic cells and macrophages. The width of the cisterns of the scabrous endoplasmatic reticulum - a trait that characterizes the synthetic activity of plasmatic cells - somewhat exceeded the values determined for smolts Salmo salar and S. trutta. The number of phagosomes on the sections of macrophages was twice as high as that on the sections of cells of $S$. salar and was comparable to this parameter in cells of $S$. trutta (Flerova et al., 2020).

It has to be noted that according to the number of granules on the section of granulocytes, smelt is closer to $S$. salar and S. trutta at the stage of smoltification than freshwater Esox lucius (Flerova \& Balabanova, 2013; Flerova et al., 2020). At the same time, ultrastructure and amount of granules of neutrophils of smelt corresponded to such in E. lucius (Flerova \& Balabanova, 2013). Frequency of abundance of neutrophils on the sections of mesonephros with particular type of granules, and also the number of granules on the section of neutrophils and eosinophils, were most likely related to the peculiarities of functioning of the cellular link of the immune system in particular conditions of the species environment.

In general, sizes of leukocyte cells of smelt corresponded to blood cells of the mesonephros of smolts of S. salar (Flerova et al., 2020).

The cells with radially positioned vesicles, found in the interstitium of mesonephron of smelt, had the same structure pattern as such type of cells described for smolts of S. trutta and freshwater fish Oncorhynchus mykiss, E. lucius. Size of cells with radially arranged vesicles corresponded to such value of cells of $S$. salar (Balabanova, 2006; Flerova, 2017; Flerova et al., 2020). Ultrathin structure of ion-transporting cells overall corresponded to $S$. salar and S. trutta at the stage of smoltification (Flerova et al., 2020). It has to be noted that the number of mytochondria on the section of the cells - the main indicator that characterizes the functioning of iontransporting cells - was closer to this indicator for the cells of $S$. salar and S. trutta compared with freshwater fish (Flerova, 2017; Flerova et al., 2020).

Analysis of the main sections of the nephron indicated that the renal interstitium had the same structure pattern as the representatives of Salmoniformes (Anderson \& Loewen, 1975; Flerova et al., 2020). Diameter of the renal corpuscle was greater than in Esox lucius (Flerova, 2017). At the same time, the cavity of the renal corpuscle had a two times narrower lumen compared with such in nephrons of smolts of S. salar and S. trutta. Thickness of the basal membrane four times exceeded this parameter for smolts of $S$. salar and S. trutta. On one hand, large renal corpuscles indicate filtration of a large amount of liquid, and on the other hand such morphometric parameters as narrow lumen of the renal corpuscle and thick basal membrane indirectly suggest lower rates of glomerular filtration in smelt during spawning migration as compared with the Baltic population of anadromous young Salmoniformes (Flerova et al., 2020). In nephrons of smelt, no neck segment was found, which was earlier detected in the kidneys of some species of freshwater fish (Ojeda et al., 2006; Flerova, 2017). Height of epitheliocytes of the proximal tubules was greater in smolts of S. salar and S. trutta and corresponded to the values of the pink salmon Oncorhynchus gorbuscha (Walbaum, 1792) traveling to spawning migration and captured when approaching spawning sites in the river (Maksimovich et al., 2000).

On the sections of the proximal tubules, rarely occurring brush cells were observed. On the sections of epitheliocytes of the proximal tubules, there were seen folds of smooth endoplasmatic reticulum. On the sections of distal tubules, the invaginations of cytoplasmic membrane were found on lobe-like projections. The number of mitochondria and development of smooth endoplasmic reticulum on the sections of proximal canals of the smelt corresponded to $S$. salar at the stage of smoltification. The number of mitochondria on the sections of the distal tubules of smelt was lower than in smolts of S. salar (Flerova et al., 2020). It is generally accepted that the brush segments of nephron (the neck section and the brush cells of proximal canals) are involved in the movement of liquid. The brushes contribute to the flow of urine from the renal corpuscle to the proximal tubules, reducing the pressure in the urine-removing space and therefore increasing the rates of the glomerulus filtration (Ojeda et al., 2006). The study of nephrons of euryhaline species - rainbow trout, also revealed absence of neck segment and low number of brushes in the brush border. This study demonstrated that in the proximal tubules, in base-laterally positioned membranes of well-developed smooth endoplasmic reticulum, a large amount of $\mathrm{Na}^{+} / \mathrm{K}^{+}$-ATPase was found. In the distal tubules of rainbow trout, there were seen apically-located $\mathrm{Na}^{+} / \mathrm{K}^{+} / 2 \mathrm{Cl}^{-}$cotransporters that participate in the secretion of ions in case of fast changes in salinity of the environment. Through the distal tubules, renal regulation is possible by switching between secretion and absorption depending on the osmoregulatory needs of the species (Katoh, 2008).

\section{Conclusions}

Comparison of the structural peculiarities of mesonephrosis of semianadromous species Osmerus eperlanus making spawning migrations with cells that develop the kidneys of freshwater and anadromous Salmoniformes gives grounds to consider the developments of hematopoietic tissue in the studied organ, and the number of mature forms of granulocytes as systematic signs, independent from species ecology. The ratio of leukocytes, width of the cisterns of the scabrous endoplasmic reticulum of plasmatic cells, structure and amount of granules in granulocytes are related to peculiarities of functioning of cellular link of the immune system in particular conditions of species environment. Ultrathin structure of iontransporting cells of the interstitium, and also the ultrastructural peculiarities found in the nephron of smelt may be considered cytological markers of adaptation of smelt to a semi-anadromous way of life.

The authors wish to express sincere appreciation to the workers of the Laboratory of the Monitoring of Salmonidae Populations at the Saint Petersburg Branch of VNIRO (GOSNIORKH named after L. S. Berg) for help in collecting the material and Centre of collective usage "S.M.I." for processing the digital photos.

Financial support: Russian Ministry of Science and Higher Education, Project No. 0856-2020-0008.

\section{References}

Anderson, B. G., \& Loewen, R. D. (1975). Renal morphology of freshwater trout. American Journal of Anatomy, 143(1), 93-113.

Artamonova, V. S., Kolmakova, O. V., Kirillova, E. A., \& Makhrov, A. A. (2018). Phylogeny of salmonoid fishes (Salmonoidei) based on mtDNA COI gene sequences (barcoding). Contemporary Problems of Ecology, 11(3), 271-285.

Balabanova, L. V. (2006). Kletki s radialno raspolozhennymi vezikulami u rybraznyh vidov [Cells with radiating vesicles in different fish species]. Cytology, 48(8), 636-640 (in Russian).

Becker, K., Fishelson, L., \& Amselgruber, W. M. (2001). Cytological ontogenesis and involution of the thymus and head-kidney in juvenile and old domestic carp: Is ageing in fish a chronological or growth-related phenomenon? Journal of Applied Ichthyology, 17, 1-13.

Björnsson, B. T., \& Bradley, T. M. (2007). Epilogue: Past successes, present misconceptions and future milestones in salmon smoltification research. Aquaculture, 273, 384-391.

Flerova, E. A. (2017). Osobennosti struktury mezonefrosa obyknovennoy shuki Esox lucius L. [Features of mesonephros structures common pike Esox lucius]. Problems of Fisheries, 18(4), 487-498 (in Russian).

Flerova, E. A., \& Balabanova, L. B. (2013). Ultrastructure of granulocytes of teleost fish (Salmoniformes, Cypriniformes, Perciformes). Journal of Evolutionary Biochemistry and Physiology, 49(2), 223-233.

Flerova, E. A., Sendek, D. S., \& Yurchenko, V. V. (2020) Specific features of the ultrastructure of mesonephros of smolts of the Atlantic salmon Salmo salar L. (Baltic Sea population) and brown trout Salmo trutta L. Inland Water Biology, 13(3), 445-454. 
Katoh, F., Cozzi, R. R. F., Marshall, W. S., \& Goss, G. G. (2008). Distinct $\mathrm{Na}^{+} / \mathrm{K}^{+} / 2 \mathrm{Cl}$ cotransporter localization in kidneys and gills of two euryhaline species, rainbow trout and killifish. Cell and Tissue Research, 334(2), 265-281.

Keyster, I. A. (2009). Morfologicheskiy sostav krovi ryapushki i eyo izmeneniya kak bioindikatsionnyie pokazateli usloviy obitaniya v Belom ozere (Vologodskaya oblast) [Morphological structure of blood of vendace and its changes as bioindicators of Beloe Lake (Vologda Region)]. Modem problems of science and education, 3, 117-125 (in Russian).

Kocabatmaz, M., \& Ekingen, G. (1987). Comparative studies on leucocytes of some freshwater fish species. Selçuk Üniversitesi Veteriner Fakültesi Dergisi, 3(1), $71-81$.

Lapirova, T. B., Flerova, E. A., Yurchenko, V. V., \& Morozov, A. A. (2017). Protective systems of immune-competent organs in the fish of various ecological and systematic groups. Journal of Ichthyology, 57(3), 458-466.

Maksimovich, A. A., Serkov, V. M., Zagal'skaya, E. O., \& Kudra, A. A. (2000). Ultrastructure and function of proximal tubular cells of nephrons of pacific salmons adapted to environments with different salinity. Journal of Evolutionary Biochemistry and Physiology, 36(3), 334-345.

Maksimovich, A. A. (2008). Evolutionary physiological aspects of adaptation of the pacific salmon fry of the Oncorhynchus genus to migration to the sea water. Journal of Evolutionary Biochemistry and Physiology, 44(1), 58-68.

Mikryakov, D. V., Pronina, G. I., Suvorova, T. A., \& Petrushin, A. B. (2019). Nekotorye pokazateli gumoral'nogo i kletochnogo immuniteta molodi soma obyk- novennogo, perebolevshego ihtioftiriozom [Some indicators of humoral and cellular immunity of young catfish, who had ichthyophthiriasis]. Trudy VNIRO, 175, 104-111 (in Russian).

Mizuno, S., Misaka, N., \& Kasahara, N. (2001). Morphological changes in juxtaglomerular cells of the kidney during smoltification in masu salmon Oncorhynchus masou. Fisheries Science, 67(3), 538-540.

Ojeda, J. L., Icardo, J. M., Wong, W. P., \& Ip, Y. K. (2006). Microanatomy and ultrastructure of the kidney of the African lungfish Protopterus dolloi. The Anatomical Record Part A: Discoveries in Molecular, Cellular, and Evolutionary Biology, 288A(6), 609-625.

Resende, A. D., Lobo-da-Cunha, A., \& Rocha, E. (2012). Comparative summary of the fish renal structure, using the brown trout (Salmo trutta) as the reference model. Microscopy and Microanalysis, 18(5), 47-48.

Resende, A. D., Lobo-da-Cunha, A., Malhao, F., \& Franquinho, F. (2010). Histologi$\mathrm{cal}$ and stereological characterization of brown trout (Salmo trutta f. fario) trunk kidney. Microscopy and Microanalysis, 16, 677-687.

Sendek, D. S., \& Bogdanov, D. V. (2019). European smelt Osmerus eperlanus in the eastern gulf of Finland, Baltic Sea: Stock status and fishery. Journal of Fish Biology, 94, 1001-1010.

Yasuike, M., Jantzen, S., Cooper, G. A., Leder, E., Davidson, W. S., \& Koop, B. F. (2010). Grayling (Thymallinae) phylogeny within salmonids: Complete mitochondrial DNA sequences of Thymallus arcticus and Thymallus thymallus. Journal of Fish Biology, 76(2), 395-400. 